Document downloaded from:

http://hdl.handle.net/10251/67104

This paper must be cited as:

Expósito Langa, M.; Tomas Miquel, JV.; Molina Morales, FX. (2015). Innovation in clusters: exploration capacity, networking intensity and external resources. Journal of Organizational Change Management. 28(1):26-42. doi:10.1108/JOCM-10-2013-0192.

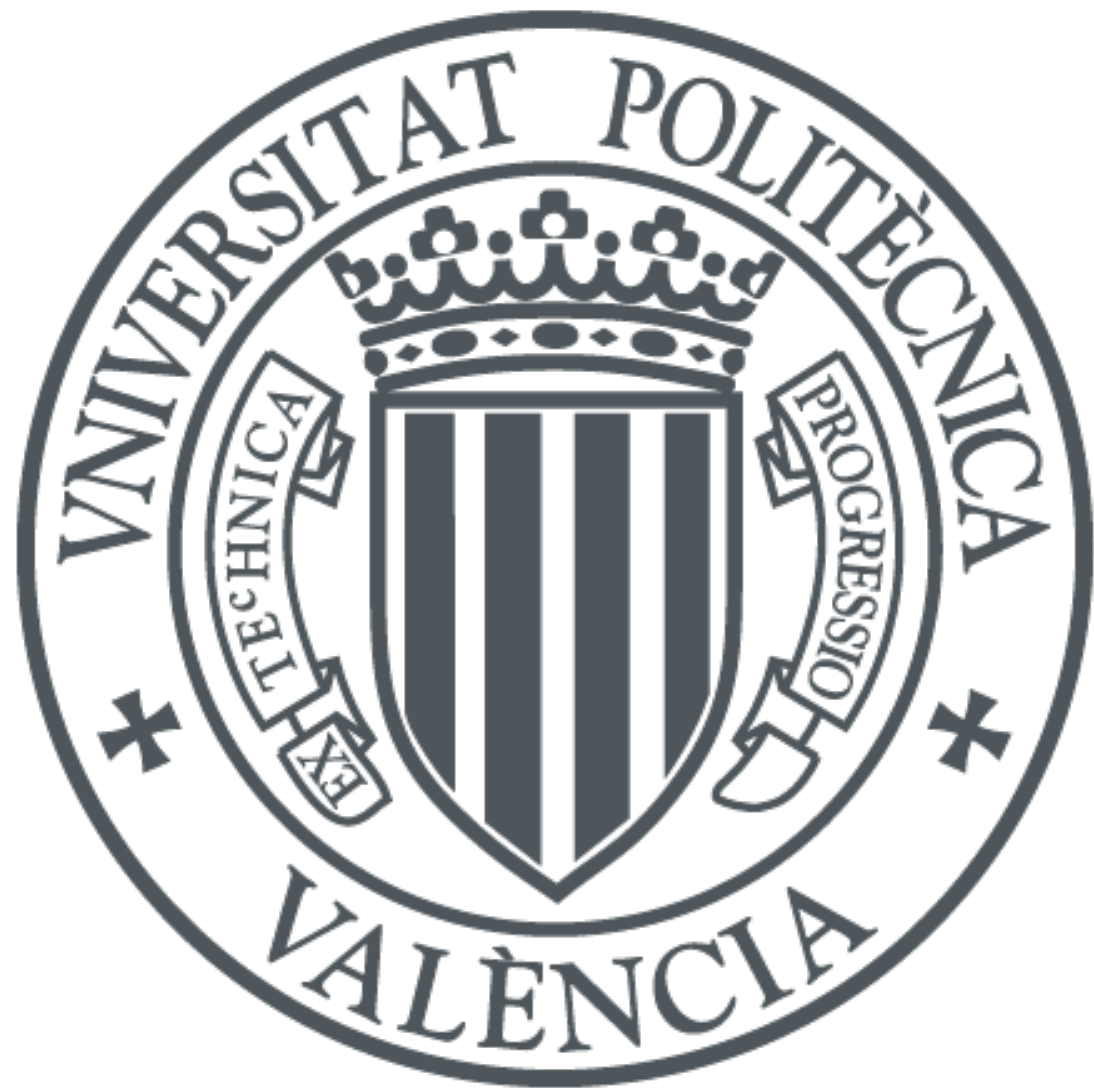

The final publication is available at

http://dx.doi.org/10.1108/JOCM-10-2013-0192

Copyright Emerald

Additional Information

"This article is (c) Emerald Group Publishing and permission has been granted for this version to appear here https://riunet.upv.es/. Emerald does not grant permission for this article to be further copied/distributed or hosted elsewhere without the express permission from Emerald Group Publishing Limited" 


\title{
INNOVATION IN CLUSTERS: EXPLORATION CAPACITY, NETWORKING INTENSITY AND EXTERNAL RESOURCES
}

\author{
Manuel Expósito-Langa
}

(Corresponding author)

Universitat Politècnica de València, Business Administration Department

Plaça Ferràndiz i Carbonell 2, 03801. Alcoi (Alacant), Spain

$$
\begin{gathered}
\text { Tel: +34966528466 } \\
\text { Fax: +34966528585 } \\
\text { maexlan@doe.upv.es }
\end{gathered}
$$

\section{José-Vicente Tomás-Miquel}

Universitat Politècnica de València, Business Administration Department Plaça Ferràndiz i Carbonell 2, 03801. Alcoi (Alacant), Spain jotomi@doe.upv.es

\section{F. Xavier Molina-Morales}

Universitat Jaume I, Business Administration and Marketing Department Avda. Vicent Sos Baynat, 12071. Castelló de la Plana, Spain xavier.molina@emp.uji.es 


\section{INNOVATION IN CLUSTERS: EXPLORATION CAPACITY, NETWORKING INTENSITY AND EXTERNAL RESOURCES}

\section{Structured Abstract:}

\section{Purpose}

This work presents an integrated model of the determinants of innovation in clusters. In our understanding, internal, external and relational dimensions must be considered to make up a complete picture of the innovation processes. We propose that the exploration capacity of the firm, as well as its networking intensity and the external resources provided by supporting organizations are relevant in this context.

\section{Design/methodology/approach}

The empirical study has drawn on the population of the firms belonging to the Valencian textile industrial cluster in Spain and was carried out in two different phases. In the first step we applied the social network analysis technique to study the relational structure of the participating companies, followed by a second analysis aimed at performing a more detailed analysis of the companies that answered the roster by means of face-to-face interviews.

\section{Findings}

Results suggest that firms in clusters must develop individual capacities parallel to the systemic resources in order to improve their innovation performance. These systemic resources are provided by the position in the knowledge network and the relations with KIBS (Knowledge Intensive Business Services), as agents that connect the cluster with external networks.

\section{Originality/value}

In spite of diverse contributions, previous research only provides a partial explanation of the issue and others underestimate one of the elements (internal or external to the firm) where the sources of innovation are generated. The originality of this study lies in the fact that it presents a complete perspective of the innovation process in clustered firms and clarifies key questions in cluster studies through network analysis techniques.

Keywords: Cluster, Exploration, Innovation, KIBS, Network analysis

\section{INTRODUCTION}

Industrial clusters (Porter, 1990) have traditionally received a great deal of attention in both the academic and the policy fields. Widely known as geographic agglomerations of economic activities that operate in the same or interconnected sectors (Giuliani and Bell, 2005), recent cluster literature has shifted to devote a lot of attention to innovation processes. 
It is frequently argued that this category of network provides substantial benefits for the companies involved in terms of knowledge flows (Uzzi, 1996). This literature has also underlined the capacity of clustered firms for knowledge creation and diffusion and, as a consequence, to improve innovation performance (Huggins and Johnston, 2010; Martínez et al., 2012).

Innovation has been studied in a variety of contexts. Oslo's Manual defines four types of innovation: product, process, marketing and organizational innovation (OCDE, 2005). An accurate definition of innovation considers it as the successful introduction of a new thing or method. Innovation is the embodiment, combination, or synthesis of knowledge in original, relevant, valued new products, processes, or services (Luecke and Katz, 2003). We are aware of the difficulties involved in assessing innovation performance in such specific contexts. There are several reasons why many companies do not use patents to protect this knowledge (Grant, 1996), so instead we followed the recommendation of Tushman and Nadler (1986), who related innovation to new product, service or process creation in terms of business units.

However, researchers seem to be abandoning a simplistic approach to the effect of clustering on firms. In fact, the focus of many of the recent contributions seems to have shifted towards the role of firms' internal resources and capabilities (Hassink, 2008). Probably the reasons behind this change come from the cluster's difficulties in coping with external challenges in the current globalised markets (Gupta and Subramanian, 2008). Poor innovation capacities and different types of lock-in are mentioned as the main reasons for the progressive decline of some industrial clusters (Trippl and Otto, 2009).

Contradictory findings suggest that some relevant questions still have to be addressed properly. In our opinion, much of the previous research provides only a partial explanation or the studies fail to find where the sources of cluster innovation are generated.

In order to address the determinants of innovation in cluster firms, some considerations must be made. As we understand it and in line with some previous research (Bell, 2005; Hipp and Grupp, 2005; Capaldo, 2007; Hassink, 2008), different dimensions should be regarded in order to provide a comprehensive picture of the innovation processes in 
clusters. Particularly we are referring to the internal, external and relational dimensions. We have specifically conceptualized the internal dimension as the exploration capacity of the firm, the external one through the influence of KIBS (Knowledge Intensive Business Services) within the cluster and, finally, the relational one as the networking intensity of the firm. The expected contribution of our research is to provide a better understanding of the combined effects of exploration, structural dimension and local KIBS on the cluster firms' innovation. To analyse this proposal we have focused on a Spanish textile cluster located in the Valencia Region.

Finally, we have structured this paper as follows: first, we explain the theoretical framework and research questions. Second, we describe the method and empirical study conducted on one of the Spanish textile clusters, and finally we discuss findings and potential implications.

\section{THEORETICAL FRAMEWORK}

Industrial clusters can be defined as a network of inter-organizational relationships between different actors, such as customers, competitors, suppliers, support organizations and local institutions and others (Piore, 1990), in which geographical proximity and a strong feeling of belonging are primary elements facilitating such relationships, based on norms and values such as trust and reciprocity, among others (Antonelli, 2000).

We have used the network as a metaphor to explain the relational characteristics of clusters. Some previous literature supports the conciliation of cluster and network. A cluster is identified as a network within a production context in a geographically defined area (Boschma and Ter Wal, 2007; Parrilli and Sacchetti, 2008). Thanks to geographical proximity, common learning and knowledge flows between different actors become frequent phenomena. Thus, spaces and the idea of networks as vehicles of knowledge transfer and diffusion greatly overlap (Boschma and Ter Wal, 2007). The network of relationships among firms is typically characterized as a web of dense and overlapping ties in which knowledge rapidly diffuses. Accordingly, inside the cluster, knowledge resources flow quickly, which results in reduced search costs (Maskell, 2001). In addition, the dynamics of knowledge exploitation is different to that produced in other 
contexts, which facilitates the learning process and generates beneficial effects for all the firms in the group.

Nevertheless, as we mentioned previously, poor innovation capacities and the consequent progressive decline of some industrial clusters has led researchers to reconsider the main drivers for cluster innovation and to move the focus to the role of firms' internal resources and capabilities (Hassink, 2008). In this vein, our theoretical proposal recognizes the cluster's internal heterogeneity, thus granting a prominent role to the individual firm characteristics (Boschma and Ter Wal, 2007). Specifically, the exploration capability refers to the learning process in which a firm invests resources and energies to acquire entirely new knowledge, skills, and processes (March, 1991; Yalcinkaya et al., 2007). We conceptualized exploration capabilities as the strategic insights that enable importers to recognize the intrinsic value of other resources or to develop novel strategies before competitors (Collis, 1994).

Secondly, we assume the potential relevance of the portfolio of relationships of clustered firms (Capaldo, 2007; Coombs et al., 2009; Molina-Morales and MartinezFernandez, 2009) and the existence of specific external resources in the cluster provided by KIBS (Hipp and Grupp, 2005). The portfolio of relationships of a firm can be identified as the Egonet size that measures the number of connections in the social network developed by the actor (ego), considering a social network as the set of actors and the ties among them. With respect to the specific external resources in the cluster we have specifically focused on the so-called Knowledge Intensive Business Services (KIBS). Following Bettencourt et al. (2002: 100-101) KIBS are enterprises whose primary value-added activities consist of the accumulation, creation, or dissemination of knowledge for the purpose of developing a customized service or product solution to satisfy the client's needs. KIBS provide specialized knowledge, operating as an interface between their clients' knowledge base and the wider knowledge base of the economy. KIBS consequently play an important role in the development and commercialization of new products, processes and services (Muller and Doloreux, 2009). These institutions include R\&D services, consultancy activities, financial, technical and training services, and so on. In the context of the cluster, regional KIBS are defined as KIBS which offer services within a specific cluster.

\section{Hypotheses}


Exploration behaviour in a firm can be characterized by search, discovery, experimentation, risk taking and R\&D effort (March, 1991). As might be expected, exploration is related to innovation results, particularly through the external information sources (O’Connor, 1998; Rigby and Zook, 2002, Liao et al., 2010). Since innovation is a knowledge-intensive process, we would therefore expect higher levels of exploration to be positively related to more effective innovation outcomes (Stock et al., 2001; He and Wong, 2004). In fact, several authors have shown a strong correlation between R\&D intensity and measurements of innovation output (Kamien and Schwarz, 1982; Cassiman and Veugelers, 2002; Vega-Jurado et al., 2008).

Exploration means identification of external knowledge and refers to the capacity of a company to localize and acquire external knowledge that is critical for its activity. It can be assimilated to the notion of competitive scanning (McEvily and Zaheer, 1999), which has been associated with the innovative capacity of the firm. Generally speaking, competitive scanning is related to activities involved in controlling and analysing the environment in order to detect both opportunities and threats.

Exploration capacity is influenced by several factors, such as prior knowledge that a firm has available (Cohen and Levinthal, 1990), as well as knowledge derived from recent scientific research (Zahra and George, 2002). Without a doubt, a firm's capacity to identify external knowledge is directly associated to its innovative capacity and, consequently, as more and better knowledge sources emerge, the greater the possibility of exchanging and combining innovation-associated knowledge will be.

In clusters, the exploration capacity of the individual firm may positively affect its capacity to innovate (Hassink, 2008). Clustered firms receive a large amount of knowledge and other resources from the other members of the cluster. In consequence, innovation performance primarily depends on the exploration capacity of the individual firm as regards these external resources. Therefore, it is important that exploration activity varies among firms in the cluster. Accordingly, we can formulate the following hypothesis:

H1. Exploration capacity will be positively associated with innovation results of the clustered firms. 
Clustered firms acquire a large number of knowledge resources from the other members of the cluster. In this sense, knowledge resources flow rapidly within the cluster, thus reducing search costs (Maskell, 2001) and creating a situation where the dynamics of knowledge exploration and exploitation are different to what is generally produced in other contexts, thereby facilitating the learning process and having beneficial effects for the entire group of firms. In spite of the general consensus on the relevance of connectedness to the network, recent literature is increasingly in agreement with the idea that not all firms in a cluster are equally involved in local networks (Bathelt et al., 2004; Giuliani, 2007). While geographical proximity can facilitate connectivity to stable market relationships between cluster companies, knowledge flows would be restricted to other local communities within the cluster, identified by their knowledge assets, innovative behaviour and economic performance (Morrison and Rabellotti, 2009).

Thus, business networks are established in an open and unplanned form from local interactions, with market, social and institutional relationships coexisting within the cluster (Giuliani, 2007). Resources are exchanged and combined though network channels. These resources may include information and knowledge assets. However, as suggested by Giuliani (2007), the most valuable knowledge - particularly that related to innovation - is distributed unevenly and asymmetrically among cluster companies. In this sense, the pursuit of such knowledge leads firms to strategically select diverse partners that can bring them benefits, for instance in terms of solutions for solving problems, and it is often irrelevant whether they are connected to the business network or not. Thus, knowledge networks emerge within the cluster, being made up of actors with a similar knowledge base and interest in knowledge sharing. These networks will present different characteristics from those of business networks.

In conclusion, the positive association between social interactions and knowledge acquisition is consistent with the assumptions that learning, particularly that involving difficult-to-transfer information, is aided by intensive and repeated interactions. Thus, social interactions exert an influence on the capabilities of firms and, hence, constitute a contributing factor to company innovation. Nevertheless, the cluster structure can be observed through two different networks of actors: the business network and the knowledge network. In consequence, while firms included in the business network are mainly developing market relationships, firms in the knowledge network have more 
access to information and knowledge sources, thus gaining advantages in innovation activities.

Therefore, relational or social resources have become central in explaining the behaviour and performance of organizations (Nahapiet and Ghoshal, 1998). The fundamental explanatory tenets of the social network perspective are based on the idea that the structure of social interactions enhances or constrains access to valued resources (Presutti et al., 2007; Martínez et al., 2012). On the other hand, we have distinguished between two networks in such a way that one of them, the knowledge network, is the one which represents the sources of knowledge resources for the clustered firms, and not the business network, which represents more formal or merely spatial proximity. Consequently, belonging to the knowledge network can be expected to be related to the innovation of the clustered firms, but not necessarily for the case of the business network. We can express this more formally as the following hypothesis:

$\mathrm{H} 2$. Belonging to the knowledge network will be positively associated to innovation results for clustered firms.

More recently, researchers have devoted special attention to local knowledge spillovers when examining the agglomeration effects on innovation (Audretsch and Lehmann, 2005; Bell, 2005; Thomson and Fox-Kean, 2005). In clusters, intermediary agents may mediate between internal and external networks of the clustered firms (McEvily and Zaheer, 1999). Following Bettencourt et al. (2002), KIBS are enterprises and institutions whose primary value-added activities consist in the accumulation, creation or dissemination of knowledge for the purpose of developing a customized service or product solution to satisfy the client's needs.

KIBS in clusters are identified by some institutions that are engaged in the production and diffusion of knowledge, such as public research centres, universities and other educational institutions. KIBS provide customized problem-solving assistance to cluster firms through tacit and coded knowledge exchange, and they play a two-fold role, acting as an external knowledge source for their client firms and introducing internal innovation.

Finally, KIBS play a more central role in innovation as knowledge conveyors, producers and mediators in regional economies (Hipp and Grupp, 2005; Strambach, 
2008). Cluster firms have particular conditions to identify external knowledge. Currently, in many cases firms in clusters are SMEs that have no direct access to external networks or international business relationships. Thus, cluster KIBS may become gatekeepers, acting as intermediaries between cluster firms and external sources of knowledge, enabling this knowledge to be further distributed within the regional system. Thus, KIBS are particularly valuable because of their centrality and bridging qualities, which offer focal firms access to a variety of knowledge resources (McDermott et al., 2009). Consequently, if a firm intensifies its connectedness to cluster KIBS, it will have more opportunities to exchange and combine resources in the network and, as a result, this will have a positive effect on innovation. Thus, we can formulate the following hypothesis:

H3. External resources from KIBS will be positively associated to innovation results for clustered firms.

\section{METHODOLOGY}

\section{Research setting}

The textile industry is one of the most complex manufacturing industries, and is a sector with an enormous number of possible activities involved, from yarn to fabric or knitwear production. In 2011 the textile and clothing industry in Spain accounted for $6 \%$ of industrial employment, 3\% of the GDP and 5.9\% of Spanish industrial exports. This industry has traditionally played a central role in the Spanish pattern of specialization, being one of the most representative of the local agglomerations in Spain. In fact, this sector shows the highest degree of geographical concentration in this country.

Recently in Europe, shifts in international markets, such as international textile trade liberalization or the introduction of new production technologies have caused new developments in this industry, such as a displacement of the internal low added-value activities to external locations, and consequently there has been a substitution of internal activities for new ones producing superior and higher added-value products. It should be noted that the textile sector has been the focus of many researchers in the cluster literature (Sammarra and Belussi, 2006; Crestanello and Tattara, 2011). 
Facing increasing competition from countries with emerging economies, European firms have reacted with a variety of strategies, including intense productive delocalization aimed at reducing production costs, and also policies of repositioning in higher quality segments of the market, with more added-value products and services.

In the context of the textile industry, two main traditional segments can be distinguished: clothing and household textiles. However, a third segment has recently become relevant, namely, the so-called textiles for technical use. This specialized area is focused on technological characteristics, with higher R\&D intensity requirements rather than aesthetic or decorative requirements, as can be the case of home textiles or clothing. The usual destination for these products has been industries and markets other than the traditional ones, such as the automotive industry, building sector, civil engineering, medicine or health and safety. According to the International Rayon and Synthetic Fibres Committee (CIRFS), the level of market penetration in this segment is about $25 \%$ in contrast to other traditional segments, which indicates the strong potential market for these products.

In summary, textiles for technical use is becoming a market in which Spanish cluster firms can compete, as it is based on innovative strategies rather than cost reduction. In this sense, textile firms are interested in increasing the importance of these technical textile products in their product portfolio, but are limited by their capacity for product diversification (Expósito-Langa et al., 2011).

\section{Sample collection and data sources}

The empirical study has drawn on the population of firms belonging to the Valencian textile industrial cluster in Spain. According to IVE (Valencian Institute of Economic Studies), in 2011 about 32,900 people were employed, with a production value of 4,000 million Euros, accounting for $26 \%$ and $27 \%$ of the total Spanish sector, respectively. The main products are the so-called home textiles, although in recent years technical textile production has increased considerably.

The empirical study was conducted in two different phases. Firstly, we drew up a roster of companies from the $\mathrm{SABI}^{1}$ database that included general information about firms from the textile cluster, such as their location, main activities, income, financial performance (EBT) and number of employees. As we commented earlier, the textile 
industry is made up of a wide range of manufacturing processes involving a large number of primary and auxiliary activities. Thus, there are many companies in the cluster, around 750, including micro, SMEs and large enterprises, and such a large number cannot be managed in the roster recall technique. So, in order to refine the population, we selected from the initial list the companies that are more representative based on the opinion of a panel of experts from several institutions: the Polytechnic University of Valencia and the main trade associations of the textile cluster, such as the Valencian Textile Business Association and Research Institution (ATEVAL) and the Textile Business Association from Alcoy (AETA), and two main companies in the cluster. After the application of this filter, a final sample of one hundred companies was established, thus allowing us to proceed with a representative set of enterprises from the total population addressed by this research.

The first phase of the study was developed during the period from May to July 2010. We applied the roster-recall method (Wasserman and Faust, 1994) since it has been frequently used in previous research in this particular field (Giuliani and Bell, 2005; Morrison and Rabellotti, 2009). This technique consists in sending a questionnaire out to the sample companies and attaching the complete list of these companies. They are invited to select those companies from the list with which they maintain commercial relationships (business network) and knowledge exchanges (knowledge network). The process concluded satisfactorily with a total of 79 completed questionnaires being obtained.

In order to complete our analysis, in the second phase of the study we used face-to-face interviews with the aim of performing a more detailed analysis of the companies that answered the roster. Finally we carried out semi-structured interviews with company CEOs and executives. These companies were interviewed during the period from September to November 2010. These interviews allowed us to gain a detailed understanding of company activities, market strategies, product portfolio, as well as the firm's orientation towards innovation process development.

\section{Variables}

\section{Dependent Variable}

\section{- Innovation, creation of new products}


This variable attempts to capture the company's capacity to create and generate new products. In the context of our research we have characterized the development of new products based on the degree to which they are focused on the technical textiles segment. Consequently, in the context of our research we have associated innovation with the degree to which a firm dedicates its product portfolio to technical textiles, since we can assume that this segment implies new products (or a line of new products) for the textile industrial cluster. We can find support for the use of this indicator in previous research on this particular industry (Expósito-Langa et al., 2011). The variable was made operational through the single item: What percentage of the products your company produces is for the technical textile segment?

To avoid limitations of self-assessment of innovation results by companies we ran a control of measures by a panel of experts, following the suggestions of Bell (2005). Indepth interviews were also carried out with a panel of experts from the AETA Association. During the session we presented the list of companies to the panel of experts for them to value the innovative output in each case, the aim being to try to reach a consensus among all participants, which was finally captured in a 1-5 Likert scale. As a result of the meeting with experts we elaborated a control measure to assess the innovation of a company. Then we computed the bivariant correlation between experts' and firms' perceptions, which resulted in a satisfactory correlation at .672 $(p<.01)$. We thereby consider that the item used in our study captures the firm's innovation results adequately.

\section{Independent variables}

\section{- Exploration capacity}

Exploration capacity captures the essence of the exploration of new possibilities, emphasizing the development of new skills, knowledge and processes of an organization (March, 1991; Yalcinkaya et al., 2007). To operationalize the variable, we proposed a number of items related to the evaluation of the degree of commitment of the company towards R\&D activities. The first item is defined as the commitment and concern of the management of the company towards R\&D and was formulated following Jansen et al. (2005). In accordance with other contributions, such as Mangematin and Nesta (1999), Zahra and George (2002) and Jansen et al. (2005), 
respondents were asked about $R \& D$ and the importance of cooperation for knowledge acquisition by using a second item. We asked for the company's participation in R\&D programmes (at regional, national or European levels) over the last three years. Finally, the last item was related to the percentage spent on $R \& D$ in relation to total sales (as innovation effort).

An exploratory factor analysis was run to identify the multi-item scale of the exploration capacity construct. A Cronbach's $\alpha$ value of 0.834 was obtained and the results of the factor analysis reported by the Barlett test of sphericity were significant (Chi-square $=90.358 ; \mathrm{df}=3 ;$ sig.=.000). Finally, the Kaiser-Meyer-Olkin (KMO) measurement was greater than $0.6(\mathrm{KMO}=.696)$. Therefore, it was appropriate to proceed with a factor analysis (Coakes and Steed, 2001). A one-factor solution was obtained with varimax rotation and $75.298 \%$ of variance extracted from the overall variance.

\section{- Knowledge/Business egonet size}

In order to make the Egonet size variable operational, we applied social network analysis techniques by using UCINET v.6 software (Borgatti et al., 2002). This technique provides a tool to explore the structural properties of a network, and encompasses theories, models, and applications that are expressed in terms of relational concepts or processes (Wasserman and Faust, 1994).

Two egonet values were obtained for the networks of each actor in order to compute their total number of ties with other cluster companies. Particularly, we asked about the ties of the company concerning both its knowledge and business networks. Thus, the former was associated to the Knowledge Egonet Size (KES) variable, and the latter to the Business Egonet Size (BES) variable. Although we used the KES variable to contrast Hypothesis 2, we applied the BES variable to control results.

On the one hand, the knowledge network facilitates the transfer of, mainly tacit, knowledge related to innovation and technical problems (Giuliani and Bell, 2005; Giuliani, 2007; Morrison and Rabellotti, 2009; Ramírez-Pasillas, 2010), which implies going one step further than the mere acquisition of information, or explicit knowledge, that could in turn come from other channels such as trade fairs, Internet, industry magazines, etc. Hence, companies were asked to select from the listing those firms that 
had helped them to solve technical problems, provided relevant knowledge or participated jointly in R\&D projects in the last 3 years.

On the other hand, business relationships are established based on business-centred interaction, such as exchanges of inputs or services, or partnerships based on a common institutional affiliation (Giuliani, 2007; Ramírez-Pasillas, 2010). Accordingly, companies were asked to select from the listing those companies with whom they had interacted on business issues in the last 3 years.

\section{- KIBS (Knowledge Intensive Business Services)}

KIBS provide specialized knowledge, operating as an interface between their clients' knowledge base and the wider knowledge base of the economy. KIBS consequently play an important role in the development and commercialization of new products, processes and services (Muller and Doloreux, 2009). These institutions include R\&D services, consultancy activities, financial, technical and training services, and so on. In the context of the cluster, regional KIBS are defined as KIBS which offer services within a specific cluster. In order to assess the ability of regional KIBS to engage in coinnovation with cluster firms, we asked firms to evaluate the perception obtained from the collaboration agreements established with this kind of local actors in their innovation processes. Note that although some contributions such as McDermott et al. (2009) categorized different types of KIBS (i.e. associations, banks, cooperatives, schools, etc.), in our case we only focused on those institutions with which cluster companies clearly establish partnerships in $\mathrm{R} \& \mathrm{D}$, research projects or technical advice rather than financial services or training. We believe that this choice is the most appropriate for the purpose of our study. Therefore, the regional KIBS considered are the Valencian Textile Technology Institute (AITEX) and ATEVAL as research institutions, and the Polytechnic University of Valencia. We used a 1 to 5 Likert scale.

\section{- Control (Size)}

Size is usually used as a control variable, and larger firms can be expected to invest more resources in obtaining new knowledge sources. The variable was measured through the logarithms of unit sales in order to smooth it. 


\section{EMPIRICAL RESULTS}

\section{Network analysis}

In this step of our analysis, and in order to analyse the relational structure of the participant companies, we used the social network analysis technique included in the software application UCINET v.6 (Borgatti et al., 2002). This technique has been used in cluster analysis by several authors (Boschma and Ter Wal, 2007; Giuliani, 2007; Morrison and Rabellotti, 2009; Ramírez-Pasillas, 2010).

Figure 1 and 2 show the Business and Knowledge networks obtained in the first phase of our analysis. As can be observed in both networks, there are significant differences in density and structure. On the one hand, the size of the nodes that appear in the figures was an indicator of their egonet size variable. This value was computed and then included in the following phase of the study.

\section{INSERT FIGURE 1 AND 2 ABOUT HERE}

\section{Regression models}

To test the hypotheses we ran a stepwise hierarchical regression approach to assess the explanatory power of each set of variables. The models are as follows:

Model 1: Innovation $=\alpha_{1}+\beta_{1}$ Exploration $+\beta_{2}$ FirmSize

Model 2: Innovation $=\alpha_{1}+\beta_{1}$ Exploration $+\beta_{2} \mathrm{KES}+\beta_{3} \mathrm{BES}+\beta_{4}$ FirmSize

Model 3: Innovation $=\alpha_{1}+\beta_{1}$ Exploration $+\beta_{2} \mathrm{KES}+\beta_{3} \mathrm{BES}+\beta_{4} \mathrm{KIBS}+\beta_{5}$ FirmSize

Model 1 represents how innovation is controlled by exploration, with firm size acting as a control variable. Model 2 incorporates the proposed structural variables and, finally, Model 3 introduces the role of KIBS, reflecting its influence on innovation. Table 1 shows the final values of the different proposed models.

The results in Model 1 support the first hypothesis, that is, the existence of a lineal and positive association between the firm's exploration capacity and innovation performance. As expected, the most proactive firms obtain better results in terms of new product developments $(\beta=.562, \mathrm{p}<.01)$. These firms diversify their product range by 
incorporating more knowledge-intensive production processes. The resulting values of the regression analysis are significantly robust and support the expected association. In addition, size was not significant as a control variable ( $\beta=-.094$, n.s.). The latter result can be explained by considering the particular condition of the cluster, where an intense division and specialization of labour occurs, which reduces the relevance of the economies of scale in comparison with other contexts.

Hypothesis 2 proposed that the knowledge network has a positive effect on the innovation performance of the clustered firm. To validate this proposition we have incorporated the KES variable for the knowledge network, and to control the result we have also incorporated the BES variable for the business network of clustered firms (according to Model 2). Results indicate that while the KES has a positive and significant effect on innovation $(\beta=.443, p<.01)$, the BES on the other hand was not significantly associated. In any case this result could be expected since belonging or being close to the knowledge network permits better access to knowledge from the cluster, thus taking advantage of new knowledge for the activities related to the innovation process of the company. On the other hand, in the case of the business network, the BES variable indicates the lack of a significant association. In our view, this result may be evidence of the poor role played by these commercial relationships in the innovation process of the clustered firms.

\section{INSERT TABLE 1 ABOUT HERE}

Finally, Model 3 tests Hypothesis 3, which expects a positive and significant association between the value of the external resources (through KIBS) and innovation results. As Table 1 shows, the effect is positive and significant $(\beta=.492, p<.01)$, thereby indicating the importance of the KIBS as providers of specific knowledge for the clustered firms. Therefore, the fact that KIBS are in contact both with firms in the cluster and external cluster circles allows them to transfer new sources of information as well as exclusive knowledge and opportunities for the clustered firms, thus reducing search costs. In conclusion, firms can obtain search economies by maintaining relationships with KIBS (Molina-Morales and Martínez-Fernández, 2003). 


\section{DISCUSSION}

The aim of this work was to capture and integrate within a single analysis three dimensions or factors that are considered determinants of innovation processes in clusters in the recent literature. Particularly, we assume that internal, external and relational dimensions complete a picture of the innovation in cluster firms.

Firstly, the exploration capacity of the clustered firms is an internal capacity related to the concept of innovation effort. Findings indicate that individual capacities are relevant for clustered firms. Thus, alongside the systemic or collective resources, firms must develop distinct capacities. These findings are in line with recent research contributions in the cluster literature that emphasize the role played by the individual firm. Secondly, a firm's egonet size has provided significant explanatory power. On the one hand, we have distinguished between two different categories of relational structures. One refers to knowledge exchanges and the other to the business or commercial exchanges. The significant association between knowledge network and innovation confirms the importance of knowledge flows in the cluster and moreover the importance of positioning within the network of the individual firm. In contrast, the lack of a significant association with the business network may require an additional comment. One possible explanation for rejection comes from the very definition of innovation used in our study. Since we considered new product development, and particularly the relative weight of textiles for technical uses, innovation is related to technological rather than other forms of non-technological innovation, such as market innovation. We are convinced that, for this new category of innovation, the importance of business networks could have been significantly different. Thirdly, external resources, provided by support organizations such as KIBS, are relevant for the innovation process of the clustered firms. In clusters we may find a wide range of supporting organizations and local institutions providing specific information, knowledge and services. These organizations can act as intermediary agents connecting dense internal networks with external unconnected networks.

In our view our paper contributes to the cluster literature in several different ways. On the one hand, it offers a comprehensive perspective of the innovation process in clustered firms. In fact, the results obtained balance the importance of each category of knowledge resource. So, while exploration capacity is important for innovation 
processes, the networking intensity of the firms to access the firm-external resources must also be considered. On the other hand, this paper belongs to the group of recent attempts to clarify key questions in cluster studies through the network analysis. In short, our findings confirm previous literature that has evidenced the relevant role of internal, external and relational resources for innovation and also the interactions between them (Cassiman and Veugelers, 2006). Moreover, while local sources of competitiveness are still crucial, firms in clusters must look to the external context, international markets, where they can place their products. In this sense KIBS play a key role by acting as gatekeepers enabling external sources of knowledge to be further distributed within the regional system.

Finally, this research suffers from some limitations that may affect the potential generalization of the conclusions and which are related to the specific features of the selected case. Focusing on one single industry may provide us with some advantages but also presents certain drawbacks. Research allows us to better control the specific aspects of this industry and to customize an innovation measure based on new products, but it would be hard to directly compare new-product-based innovation between different industries. In consequence, a broader analysis is therefore needed to analyse how other cases vary.

\section{REFERENCES}

Antonelli, C. (2000), "Collective Knowledge Communication and Innovation: The Evidence of Technological Districts”, Regional Studies, Vol. 34 No. 6, pp.535-547.

Audretsch, D.B. and Lehmann, E.E. (2005), "Does the knowledge spillover theory of entrepreneurship hold for regions?", Research Policy, Vol. 34, pp.1191-1202.

Bathelt, H., Malmberg, A. and Maskell, P. (2004), "Clusters and Knowledge: Local Buzz, Global Pipelines and the Process of Knowledge Creation", Progress in Human Geography, Vol. 28 No. 1, pp.31-56.

Bell, G.G. (2005), "Clusters, Networks, and Firm Innovativeness", Strategic Management Journal, Vol. 26 No. 3, pp.287-295.

Bettencourt, L.A., Ostrom, A.L., Brown, S.W. and Roundtree, R.I. (2002), "Client CoProduction in Knowledge-Intensive Business Services", California Management Review, Vol. 44, pp.100-128. 
Borgatti, S.P., Everett, M.G. and Freeman, L.C. (2002), Ucinet for Windows: Software for Social Network Analysis, Analytic Technologies, Harvard.

Boschma, R.A. and Ter Wal, A.L.J. (2007), "Knowledge Networks and Innovative Performance in an Industrial District: The Case of a Footwear District in the South of Italy", Industry \& Innovation, Vol. 14 No. 2, pp.177-199.

Capaldo, A. (2007), "Network structure and innovation: the leveraging of a dual network as a distinctive relational capability", Strategic Management Journal, Vol. 28, pp.585-608.

Cassiman, B. and Veugelers, R. (2006), "In search of complementarity in innovation strategy: Internal R\&D and external knowledge acquisition", Management Science, 52, 68-82.

Cohen, W. and Levinthal, D. (1990), "Absorptive capacity: A new perspective on learning and innovation", Administrative Science Quarterly, Vol. 35 No. 1, pp.128-152.

Collis, D.J. (1994), "How Valuable are Organizational Capabilities?", Strategic Management Journal, Vol. 15 No. 8, pp. 143-152.

Coombs, J., Deeds, D. and Ireland, R. (2009), "Placing the choice between exploration and exploitation in context: a study of geography and new product development", Strategic Entrepreneurship Journal, Vol. 3 No. 3, pp.261-279.

Coakes, S. and Steed, I. (2001), SPSS Analysis Without Anguish, Version 10.0, John Wiley, Sydney.

Crestanello, P. and Tattara, G. (2011), "Industrial Clusters and the Governance of the Global Value Chain. The Romania-Veneto Network in Footwear and Clothing", Regional Studies, Vol. 45 No. 2, pp.187-203.

Expósito-Langa, M., Molina-Morales, F.X. and Capó-Vicedo, J. (2011), "New Product Development and Absorptive Capacity in Industrial Districts: A Multidimensional Approach”, Regional Studies, Vol. 45 No. 3, pp.319-331.

Giuliani, E. (2007), "The selective nature of knowledge networks in clusters: evidence from the wine industry", Journal of Economic Geography, Vol. 7, pp.139-168.

Giuliani, E. and Bell, M. (2005), "The micro-determinants of meso-level learning and innovation: evidence from a Chilean wine cluster", Research Policy, Vol. 34 No. 1, pp.47-68.

Grant, R.M. (1996), "Prospering in dynamically-competitive environments: Organizational capability as knowledge integration", Organization Science, Vol. 7 No. 4, pp.375-387.

Gupta, V. and Subramanian, R. (2008), "Seven perspectives on regional clusters and the case of Grand Rapids office furniture city", International Business Review, Vol. 17, pp.371-384. 
Hassink, R. (2008), "Geography locked in decline? On the role of regional lock-ins in old industrial areas", Boschma, R. and Martin, R. (Eds.), Handbook of Evolutionary Economic Geography, Edward Elgar, Cheltenham, pp.450-468.

He, Z. and Wong, P. (2004), "Exploration vs. Exploitation: An Empirical Test of the Ambidexterity Hypothesis", Organization Science, Vol. 15 No 4, pp. 481-494.

Hipp, C. and Grupp, H. (2005), "Innovation in the Service Sector: The Demand for Service-Specific Innovation Measurement Concepts and Typologies", Research Policy, Vol. 34 No. 4, pp.517-535.

Huggins, R. and Johnston, A. (2010), "Knowledge flow and inter-firm networks: The influence of network resources, spatial proximity and firm size", Entrepreneurship \& Regional Development, Vol. 22 No. 5, pp.457-484.

Jansen, J., Van Den Bosch, F. and Volberda, H. (2005), "Managing potential and realized absorptive capacity: How do organizational antecedents matter?", Academy of Management Journal, Vol. 48 No. 6, pp.999-1015.

Kamien, M.I. and Schwarz, N.L. (1982), Market structure and innovation, Cambridge Univ. Press, Cambridge.

Liao, S., Wu, C., Hu, D. and Tsui, K. (2010), "Relationships between knowledge acquisition, absorptive capacity and innovation capability: an empirical study on Taiwan's financial and manufacturing industries" Journal of Information Science, Vol. 36 No. 1, pp. 19-35.

Luecke, R. and Katz, R. (2003), Managing Creativity and Innovation, Boston, MA: Harvard Business School Press.

Mangematin, V. and Nesta, L. (1999), "What kind of knowledge can a firm absorb?", International Journal of Technology Management, Vol. 18 No. 3-4, pp.149-172.

March, J. (1991), "Exploration and exploitation in organizational learning", Organization Science, Vol. 2, pp.71-87.

Maskell, P. (2001), "Knowledge creation and diffusion in geographic clusters", International Journal of Innovation Management, Vol. 5 No. 2, pp.213-225.

Martínez, A., Belso-Martínez, J.A. and Más-Verdú, F. (2012), "Industrial clusters in Mexico and Spain: Comparing inter-organizationsl structures within context of change", Journal of Organizational Change Management, Vol. 25 No. 5, pp.651-681.

McDermott, G.A., Corredoira, R. and Kruse, G. (2009), "Public-private institutions as catalysts of upgrading in emerging markets", Academy of Management Journal, Vol. 52 No. 6, pp.1270-1296.

McEvily, B. and Zaheer, A. (1999), "Bridging ties: A source of firm heterogeneity in competitive capabilities", Strategic Management Journal, Vol. 20 No. 12, pp.1133-1158. 
Molina-Morales, F.X. and Martínez-Fernández, M.T. (2003), "The impact of the industrial district affiliation on firm value creation", European Planning Studies, Vol. 11 No. 2, pp.155-170.

Molina-Morales, F.X. and Martinez-Fernandez, M.T. (2009), "Too much love in the neighborhood can hurt: how an excess of intensity and trust in relationships may roduce negative effects on firms", Strategic Management Journal, Vol. 30 No. 9, pp.1013-1023.

Morrison, A. and Rabellotti, R. (2009), "Knowledge and Information Networks in an Italian Wine Cluster”, European Planning Studies, Vol. 17 No. 7, pp.983-1006.

Muller, E. and Doloreux, D. (2009), "What we should know about knowledge-intensive business services", Technology in Society, Vol. 31, pp.64-72.

Nahapiet, J. and Ghoshal, S. (1998), "Social capital, intellectual capital, and the organizational advantage", Academy of Management Review, Vol. 23 No. 2, pp.242-266.

OCDE (2005), The Measurement of Scientific and Technological Activities, Oslo Manual. http://www.oecd.org/dataoecd/35/61/2367580.pdf.

O’Connor, G.C. (1998), "Market Learning and radical innovation: a cross comparison of eight radical innovation projects", Journal of Product Innovation Management, Vol. 15 No. 2, pp.151-166.

Parrilli, M.D. and Sacchetti, S. (2008), "Linking Learning with Governance in Networks and Clusters: Key Issues for Analysis and Policy", Entrepreneurship and Regional Development, Vol. 20 No. July, pp.387-408.

Piore, M.J. (1990), "Work, labor and action: Work experience in a system of flexible production", Pyke, F., Becattini, G. and Sengenberger, W. (Eds.), Industrial districts and inter-firm cooperation in Italy, International Institute for Labor Studies, Geneva, pp.52-74.

Porter, M.E. (1990), The competitive advantage of the nations, The Free Press, New York, NY.

Presutti, M., Boari, C. and Fratocchi, L. (2007), "Knowledge acquisition and the foreign development of high-tech start-ups: A social capital approach", International Business Review, Vol. 16, pp.23-46.

Ramírez-Pasillas M. (2010), "International trade fairs as amplifiers of permanent and temporary proximities in clusters", Entrepreneurship \& Regional Development, Vol. 22 No. 2, pp.155-187.

Rigby, D. and Zook, D. 2002, “Open-market innovation”, Harvard Business Review, Vol. 80 No. 10, pp. 80-89.

Sammarra, A. and Belussi, F. (2006), "Evolution and relocation in fashion-led italian districts: evidence from two case-studies", Entrepreneurship \& Regional Development, Vol. 18 No. 6, pp.543-562. 
Stock, G.N., Greis, N.P. and Fischer, W.A. (2001), "Absorptive capacity and new product development", Journal of High Technology Management Research, Vol. 12 No.1, pp.77-91.

Strambach, S. (2008), "Knowledge-intensive Business Services (KIBS) as drivers of multilevel knowledge dynamics", International Journal of Services and Technology Management, Vol. 10, pp.152-174.

Thompson, P. and Fox-Kean, M. (2005), "Patent citations and the geography of knowledge spillovers: a reassessment", American Economic Review, Vol. 95, pp.450-460.

Trippl, M. and Otto, A. (2009), "How to turn the fate of old industrial areas: a comparison of cluster based renewal processes in Styria and the Saarland", Environment and Planning, Vol. 41, pp.1217-1233.

Tushman, M.L. and Nadler, D.A. (1986), "Organizing for innovation", California Management Review, Vol. 28 No. 3, pp.74-92.

Uzzi, B. (1996), "The sources and consequences of embeddeness for economic performance of organizations: the network effect", American Sociological Review, Vol. 61, pp.674-698.

Vega-Jurado, J., Gutiérrez-Gracia, A., Fernández-de-Lucio, I. and Manjarrés-Henríquez L. (2008), "The effect of external and internal factors on firms' product innovation", Research Policy, Vol. 37 No. 4, pp. 616-632.

Wasserman, S. and Faust, K. (1994), Social Network Analysis. Methods and Applications, Cambridge University Press, Cambridge.

Yalcinkaya, G., Calantone, R.J. and Griffith, D.A. (2007), "An examination of exploration and exploitation capabilities: Implications for product innovation and market performance”, Journal of International Marketing, Vol. 15 No 4, pp. 63-93.

Zahra, S. and George, G. (2002), "Absorptive capacity: A review, reconceptualization, and extension", Academy of Management Review, Vol. 27 No. 2, pp.185-203. 
Table 1. Regression results of models

Dependent variable: Innovation

\begin{tabular}{|c|c|c|c|}
\hline & M1 & M2 & M3 \\
\hline Exploration & $\begin{array}{c}.562 * * \\
(3.438)\end{array}$ & $\begin{array}{c}.593 * * \\
(3.740)\end{array}$ & $\begin{array}{r}.344 * \\
(2.167)\end{array}$ \\
\hline KES & & $\begin{array}{r}.443 * \\
(1.767)\end{array}$ & $\begin{array}{c}.598 * * \\
(2.269)\end{array}$ \\
\hline BES & & $\begin{array}{r}-.201 \\
(-.765)\end{array}$ & $\begin{array}{r}-.319 \\
(-1.384)\end{array}$ \\
\hline KIBS & & & $\begin{array}{c}.492 * * \\
(3.088)\end{array}$ \\
\hline Control (Firm Size) & $\begin{array}{r}-.094 \\
(-.577) \\
\end{array}$ & $\begin{array}{r}-.073 \\
(-.421) \\
\end{array}$ & $\begin{array}{r}.022 \\
(.144) \\
\end{array}$ \\
\hline Model $F$ & $5.914 * *$ & $4.212 * *$ & $6.427 * *$ \\
\hline$R^{2}$ & .305 & .403 & .572 \\
\hline Adjusted $R^{2}$ & .253 & .307 & .483 \\
\hline Change in $R^{2}$ & & $.098^{*}$ & $.170^{* *}$ \\
\hline \multicolumn{4}{|c|}{$\mathrm{N}=79 ; * * \mathrm{p}<.01 ; * \mathrm{p}<.05$} \\
\hline Standardized regress & & & \\
\hline
\end{tabular}




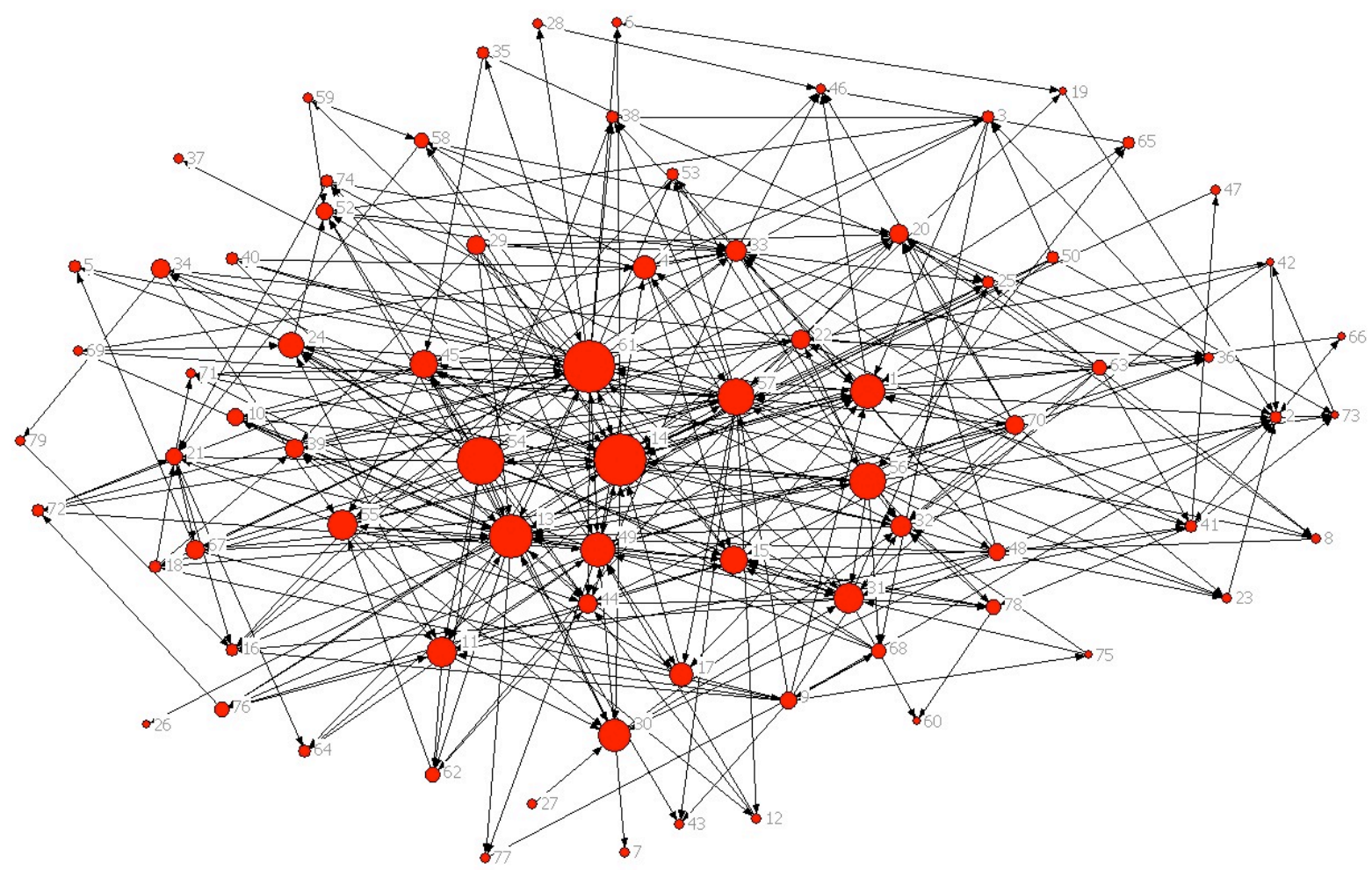

Figure 1. The Business Network of cluster firms

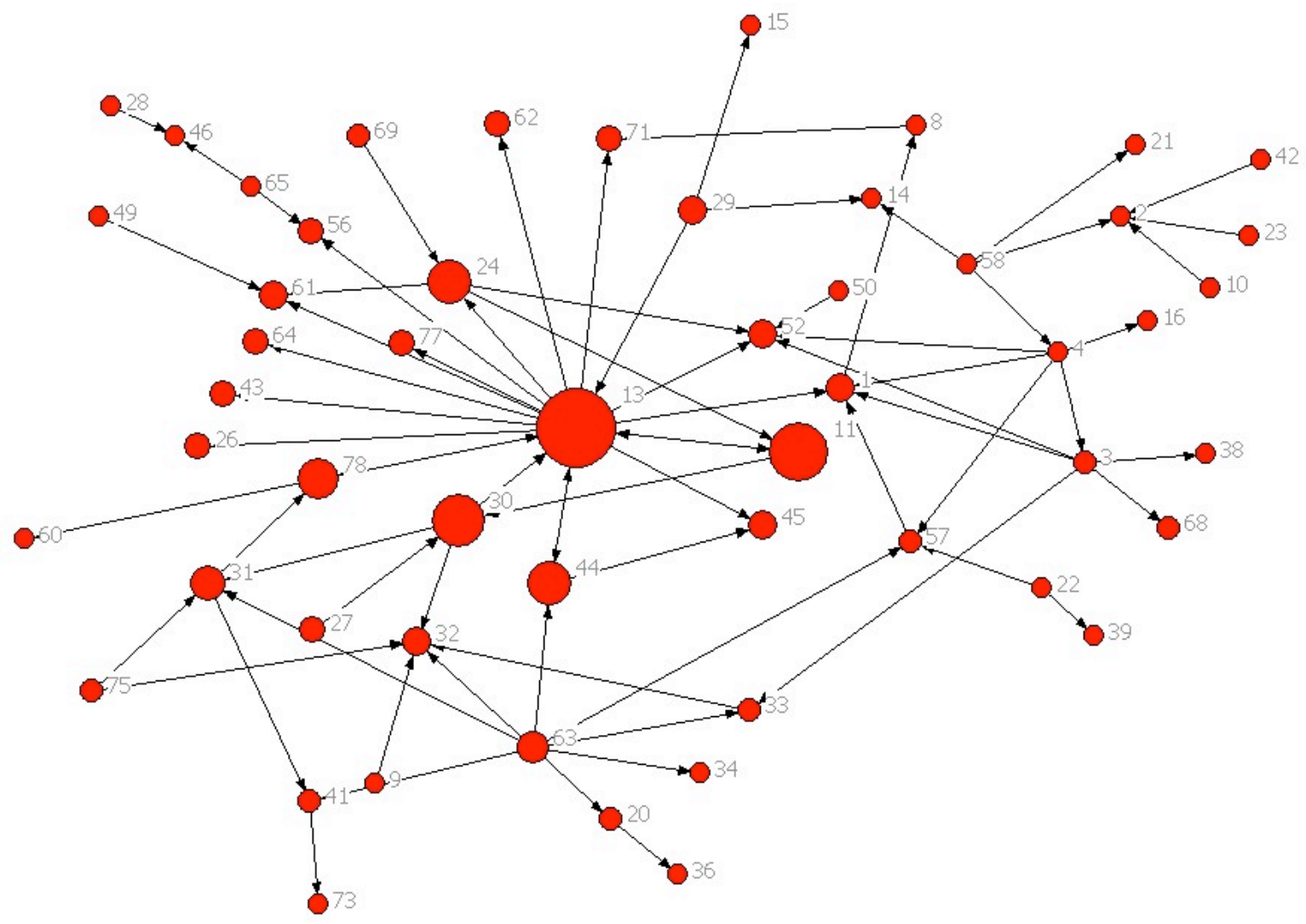

Figure 2. The Knowledge Network of cluster firms

\footnotetext{
${ }^{1}$ SABI is a directory of Spanish and Portuguese companies that collects general information and financial data.
} 